\title{
Ihsan-Based Character Education
}

\author{
Syaifulloh Yusuf \\ Department of Islamic Education \\ Universitas Islam Indonesia \\ Yogyakarta, Indonesia \\ syaifulloh.yusuf@uii.ac.id
}

\author{
Kurniawan Dwi Saputra \\ Department of Islamic Education \\ Universitas Islam Indonesia \\ Yogyakarta, Indonesia \\ 184220101@uii.ac.id
}

\begin{abstract}
The importance of character building in education is highly regarded nowadays. Recently, there rises awareness about other functions of education beside the intellectual outcome among experts and teachers. Education is no more limited to teaching lesson, but also involving other aspects such as emotional and spiritual quotient in the curriculum. In order to pursue other benefits from education, the issue of character building is concerned. Character, as explained by Ryan and Boblin, contains three interconnected elements: knowing the good, loving the good and doing the good. This research aims to propose alternative perspective about character building from Islamic point of view. The method used in this research is literature study. From Islamic perspective, character building can be built on the spirit of Ihsan. Ihsan is the third element of Islamic spiritual foundation beside Islam (rituals) and Iman (belief system). Ihsan is the sense of God's presence and supervision on human activities. Because God is immanent, individual is not only motivated to act in accordance with Islamic rules, but also inspired to unleash the divine potential within self.
\end{abstract}

\section{Keywords: Islamic Education, Character Building, Ihsan}

\section{INTRODUCTION}

Since regulated in 2017 by the presidential regulation no. 87, the PPK (Character Education Strengthening) regulation has attracted many people, agencies, and communities concerned with education to talk about [1]. This glorious response can be traced back to the socio-cultural background of Indonesian people where various customs, religions, races and etnicities live among others. Amidst differences that drive people apart, character education becomes the lingua franca for mutual moral understanding. In order to move forward as a nation, people with different cultural backgrounds agree that it is important to implement character education in state's education curriculum.

Indonesia is a large country that has a variety of customs, religions, races, ethnicities and cultures. Every culture from each region in all parts of Indonesia has its own local unique content. Customs are highly considered in order to preserve cultural legacy. However, preserving various cultural expression sometimes leads to conflict. Conflicts that occur between ethnic groups, races, religions, even between sects within a religion are problems to be solved because they will have a negative impact on the country.

The fourth paragraph 1945 Constitution states that "... advancing public welfare, educating the life of the nation ..." is Indonesian core guideline in the world of education [2]. Nation's intelligence will overcome problems that occured among religions, ethnicities, races, customs, traditions, flows, economics, social, culture and education. Imam Barnadib said that education is a conscious and systematic effort to achieve a better standard of living or progress [3]. Indonesian Law No.20 of 2003 concerning National Education System Chapter I Article 1 Paragraph 1 states that education is a conscious and planned effort to realize the learning atmosphere and learning process so that students actively develop their potential to have religious spiritual strength, self control, personality, intelligence, noble character, and various skills needed by him in order to live in harmony within society, nation and country [4].

Education and intelligence of the nation is an inseparable unit. In the world of education, intelligence cannot be judged on one criterium only. Many factors influence personal intelligence such as emotional and spiritualaspects. Spiritualintelligence can be derived from someone's character. A good character will give birth to a good leader, and vice versa. Characters can be formed not only in the realm of daily activities, but at the level of one's habits in carrying out these activities, thus forming a person who has certain characteristics.

In Islam, Qur'an and Hadith are known as the main sources of life guidance. It is often mentioned and commonly understood, that Islamic life is built on three fundamental things. First, Islam; religious pillars that occupy the lower levels of spiritual live that are expressed in daily ritual. Second, Faith; the belief foundation of religion which occupies the second level above Islam. Its lexicon, the mu'min, means someone who is truly convinced of the existence of God. Third, Ihsan; this is the highest level of religious milestones of every human being. Ihsan is said to be the highest level of Islam and Faith, because from Ihsan it is possible for someone to have faith and Islam. It is notnecessary, the mu'min also has a sense of Ihsan, just as not all people who are muslimhas true belief. So, Ihsan occupies the highest position between the three, but cannot be separated between the three.

Indonesian Muslim society is known for its Islamic devotion. Moreover, Muslim form the majority of Indonesian religious adherents. However, even if the majority of its citizen identified as religious person, Indonesian system of education does not adequately recognize the importance of character building education. Thus, the state is still far from implementing education blueprint as written in Republic of Indonesia Law No. 20 of 2003.

There are evidences that character education in Indonesia still insufficient. They are people with lack of self-control, lack of noble character, and low public awareness. For example, the issue of corruption is one of the problems related to the failure of character education in Indonesia. As reported recently, from January to April 2018, they are as many as ten 
regional head became suspects in corruption related cases [5] (news.detik.com, April 14, 2018). In the world of education, bribery in the recruitment of civil servants in Nganjuk Regency connected with Nganjuk regent, head of education service, and school principal (nasional.republika.co.id, October 26, 2017) [6]. The lack of self-control has also occurred among students, they are many student brawls, such as between students on the Jampang-Parung highway, Hambulu village, Kemang, Bogor regency resulting the death of one SMK student (metro.sindonews.com, April 19 2018) [7]. The same case occurred in West Jakarta, student brawl happened in Jalan Daan Mogot, Cengkareng, West Jakarta, and damaged motorbikes of online taxi drivers (news.detik.com, April 6, 2018) [8].

Accidents above arisen because the lack of attention to character education. Character education in the school, family and community environment is inseparable from "Ihsan". So far to date, character building education is still focused in the realm of Islam and Iman, it has not touched many aspects of Ihsan. Though this aspect of Ihsan becomes the highest degree after Iman and Islam. So that the building of "Ihsan" character in education became the focal point in the discussion of this paper.

\section{METHOD}

This study is a literature study that conducted by comparing and analyzing various references related to the issue we are addressing. As there are not yet measuring tool to analyze Ihsan in quantitative manner, we used qualitative approach. First, we address the core idea of character building education and comparing it with the concept of Ihsan from Islamic spirituality, with the reflective view on how contemporary Islamic schools are implementing character building education.

\section{RESULT}

\section{A. Education}

Education (pendidikan) in Indonesian consists of the words of "didik" (to teach) added with a prefix "pen" and a suffix "an". The word as explained in the General Dictionary of Indonesian Language means "educating actions (things, methods, etc.)" [9]. Etymologically, the word "education" which translated into Indonesian as "pendidikan" is a derivative noun from the Latin verb educare. In Latin, the word educate derived from two different verbs, educare and educere.

The word educare in Latin means training or taming (if it related with animals), fertilizing (if related with plants). So, education is a process that helps something to grow, develop, mature, organize the unorganized; a process of creating a culture and order in oneself and others. In addition, education is also a process of developing various kinds of potential that exist in humans, such as academic ability, socio-relational expertise, talents, physical prowess, or artistic intelligence [10].

According to Ahmad D. Marimba, education is a conscious guidance or a leadership by the educator towards the physical and spiritual development of the educated person towards the formation of noble personality [11]. According to R.C Lodge, education concerns the whole relations and experiences. Parents educate their children, children educate their parents, teachers educate their students, students educate their teachers, even the pet educates their masters [12].

From Islamic perspective, education according to Naquib Al-Attas is seeding and planting adab (wisdom) in a person [13]. According to Imam Barnadib, education is a conscious and systematic effort to achieve a better standard of living or progress. Education is also the process of guiding people from the darkness of ignorance to the enlightenment of knowledge. In the broadest sense, setting aside the opposition of formal and informal education, education includes everything that broadens human knowledge self and the world in which they live [14].

According to Sasono, education is an intentional effort in preparing students by growing the strength of personality, both physically and spiritually, by using good educational tools so that the students will become an adult who benefits himself, his community, and can live happily [15]. Education is a way that leads us to "reach out" ourselves. Education does not mean helping students "become aware". Sartra in Bayraktar acknowledges that, in fact, there is no difference between the two things, between being oneself and becoming aware of the self. Being yourself means to be aware of yourself. In order to be human, you have to be there, and to be there you must be aware of yourself [16].

According to Syaifulloh, education is a fundamental and conscious effort from people for others with the aim that human beings can act in providing benefits for themselves and also others [17]. Fathul Wahid, chancellor one of the private universities in Yogyakarta, believes that good education and good learning methods, can inspire people and change them [18]. Education is a very effective when the stakeholders of education system and all people that involved in education can work well together. The diverse opinions above has different point of view in the meaning of education. However, dispite all the differences, in my opinion, all agree that education must be able to humanize the human, so the educated people will benefit themselves and the surrounding community.

\section{B. Character Education}

The term character or in Indonesian is translated by the word "watak", is the prominent characteristics of a person or a group or nation that it can be recognized in various situations or is its' trade mark. From that standpoint, character education, as explained by Martadi, is the process of giving guidance to participants/students to become fully human in the complete dimensions -heart, mind, body, and feeling and intention. Students are expected to have good character including honesty, responsibility, intelligence, cleanliness and health, caring, and creativity. By possessing these characters, students are expected to become complete personalities that reflect harmony of the heart, mind, body [19]

Character education is an effort in educating children to be able to think and act wisely, both within the family, society, and nation. So community-based character education has a very important role in supporting education in schools [20]. Fostering a complete personality and character could not stop in the school environment, it must involve the community. For it is the community that will give labels for children as educated and good-manner individual [21]. Character education does not only teach what is right and what is wrong with children, more than that, character education instills 
habits (habituation) about the good so that students understand, are able to feel, and want to do good. Thus, character education carries the same mission that moral education intends [22].

The character, as defined by Ryan and Bohlin, contains three main elements: knowing the good loving the good, and doing good. In character education, goodness is often summarized in a series of good qualities. Thus, character education is an effort to guide human behavior towards good attitude. Character education must be carried out together by all teachers and principals through classroom learning and an integral part of school culture. Character education is often interpreted as personality building. Character itself is an old concept which means a set of qualities that are admired as signs of kindness, wisdom, and moral maturity. Good qualities as the goal to be achieved in character education are respect, responsibility, compassion, discipline, loyalty, courage, tolerance, and belief and love for God [23].

To create personal habit that are instilled firmly in the soul so that it unconsciously carried out actions is the goal of character education. Character education has very broad meaning. In my opinion, everyone agrees if the character can be built early through habits. However, many do not consider psyche as the base of actions. If character are judged from activity in daily basis, without concerning the psychic base, it will definitely give birth to bad conscience. If it is based on the soul, the conscience will lead someone to do good, and simultanously to have good character.

Character is also formed by the influence of the existing environment. There are teachers who have included character values in their teachings, but there are more who have not included it. There are some teachers, for example, who have used the curriculum to form characters, some have not used it. According to Yulia Citra, while most schools already have environment that supports the implementation of character education, most schools do not have policies and administration regarding character education [24]. The problem lies in the teaching staff, many teachers do not have knowledge and do not behave in line with character education. Moreover, curriculum are not implemented well by the teachers and most of the community has not supported the course of character education. If character education ideals are to be achieved, all parts of community must support it. The problem is, while many parents want their children to have character, some schools are not yet to support. On the other hand, there are schools that have excellent programs to shape children's character, but their parents do not put the attention needed. To solve these problems, it's time for us to collaborate, to remind each other and complement each other in shaping the character of children in particular, and the character of all Indonesian citizen in general.

One of few schools that have serious innovation in the field of character building education is one of the primary schools in Bantul, Yogyakarta. This school has been carried out a research to build a local uniqueness-based character education. Field trials show that teachers in this school have succeeded in implementing learning that integrates local content-based character education in many subjects [25].

Character education according to Zubaidi is divided into three parts. First, the part that focused on forming and developing potential. Character education forms and develops the potential of students to think well, be virtuous, and behave according to the values of Pancasila's philosophy. Second, the repairing and reinforcement function. In this part, character education improves and strengthens the role of families, educational units, communities, and the government to participate and be responsible for developing the potential of citizens and the development of nations towards an advanced, independent and prosperous nation. Third, filtering function. With this function, character education evaluate cultures and filters other national cultures that are not fit the values of the nation [26].

Character education in Indonesia, as stated by Zubaidi, relies mostly in filtering function. The West is different from the east culturally and traditionally. Education methods and systems also varies in different countries. Therefore, the filtering function becomes important in building the character of any nation.

In order to make the filtering function working, humans have to rely on their conscience. However, the important part is that in religious perspective, conscience does not work alone. There is something that controls and moves it: God. People are not free to act arbitrarily, because there is supervision from the Almighty. In this sense, the function of "supervision/Ihsan" as fundamental part of character education is addressed.

\section{C. "Ihsan" Character Building}

Starting from "Islam" and "Iman," the spirituality in Islam must is not a mere declaration of faith, but the faith has to be sure and therefore compassing the believe that ghaib (the unseen) exists. It is with this faith that humans will pursue themselves as muhsin. The highest degree of Islam and Faith is Ihsan. Thus, human beings are said to be muhsin if he has Iman (faith) and Islam (ritual obedience), but not to the contrary. Based on this concept, education that relies only on Islam and Iman has to be evaluated, because it did not comprehend Ihsan as foundation for education.

Ihsan-based character education is important to be reviewed because it has the characteristics needed in the design, actualization and essence of character education. First, developing the Ihsan values-based character education curriculum contained serious attention on students' behaviour. Second, the actualization of Ihsan values in the learning process is a comprehensive action because it is carried inside and outside the madrasah in eclectic and simultaneous manner. Third, has spiritual dimension because with Ihsan students' learning will be of value to worship and produce good output/outcome, which is reflected in the motto of the madrasa "we are sure, we can, bi Idznillah" [27].

One of problems with contemporary educational institutions is that the learning that is taught without explaining the purpose and benefits. As the consequence, most students do not accept the teaching materials given by the lecturer/instructor because they do not see the importance. This problem is addressed in education model that inspired by the concept of Ihsan, because in the process of learning students must aware that human existence is always supervised by God, and is sure of the existence of Allah SWT. By this awareness, students will manage their behaviour, including their attitude towards teachers and teaching material, to be in harmonious relation with God's rules. 
The design of character education based on Ihsan values is a pattern of conceptual action in the determining learning conditions and learning processes to shape one's character/attitude to be passionated in his efforts to act virtuously accompanied by sense of ma'rifatullah (knowing, being aware and feeling confident of Allah's existence). Ma'rifah means knowledge as well as the conviction in accordance with the truth, built enduring conviction on the existence of Allah [28].

Research conducted by Muhammad Arif Ihwanto found that Ihsan based character education is; first, produces a model. The values-based character education model shows that the design of the character education process carried out by teachers with students should be carried out with a solid effort accompanied by ma'rifatullah, while the design process of character education contains Ihsan values (beliefs, submission, and piety), parts of ihsan character (knowledge, feeling, and action), strategies - methods, principles, social systems and support systems; second, the meaning of Ihsan's values ends in the effort to make virtue accompanied by ma'rifatullah (knowing, being aware, and being sure of the existence of God) [29].

Ihsan values that are instilled within one's persona early in his youth will remain steady and guide his behaviour in harmonious manner with God's will. One goal of education, as often argued, is long life learning, so that it can really be useful for one's life [30]. I am arguing that the building of Ihsan's character education is a model of long life learning, because it will be the basis of one's life on learning outcomes for long-term life, beneficial for both individuals and community.

Building Ihsan-based characters is inseparable with the spirit of tasawwuf (Islamic mistic spirituality). Islamic scholars were have been addressing Ihsan when studying any scientific coverage. For example, it is also known in the history of Islamic da'wah (mission) that it has always been carried out with peace. According to the teachings of tasawwuf, if humans could not leave the physical or material form of life, they will not find the desired spiritual values. For that you have to try to release the spirit from its physical confinement. In tasawwuf, riyadah (spiritual exercise) is the way to sharpen spiritual sense in order to remain in fitrah as an original way of happiness. Achieveng goodness and happiness is not enough with knowledge, because any human expertise is a limited tool. The essential way of happiness is strongly bound with faith, the feeling of safety and peaceful life with God's supervision [31]. For this reason, there is an exact need to instill the value of Ihsan in education.

\section{CONCLUSION}

Based on the results of the discussion above regarding building Ihsan-based character education, the authors conclude that Ihsan is a very good measuring tool in building character. Because character education is the end of formal, informal and non-formal education, the measurement it used must be clear. The problem is that there are no tools that can detect Ihsan in a sophisticated way, so there is still a lack of measurement in this kind of character education. However, this paper brings readers to find realize the importance of Ihsan in character education. While most schools are focused on Islam and Iman in building character, Ihsan need to be addressed because Ihsan is the soul of Islamic spirituality.

\section{REFERENCES}

[1] Indonesian Presidential Regulation No. 87 Year 2017 on strengthening character education, signed by President Joko Widodo on September 6th, 2017.

[2] [2] UUD

194. http://www.bpn.go.id/PUBLIKASI/Peraturan-

Perundangan/Undang-Undang/undang-undang-dasar1945-931. Accessed on May 4, 2018.

[3] [3] Darmaningtyas, Pendidikan yang Memiskinkan (Yogyakarta: Galang Press, 2004).

[4] [4] UU No. 20 year 2003 http://simkeu.kemdikbud.go.id/index.php/peraturan1/8uu-undang-undang/12-uu-no-20-tahun-2003-tentangsistem-pendidikan-nasional. Accessed on May 4, 2018.

[5] [5] Theresia Feliciani. Bupati Nganjuk Jadi Tersangka Suap Perekrutan Kepala Sekolah. Www.tribunnews.com. Accessed on May 4, 2018.

[6] [6] Ibnu Hariyanto. Hingga April, 10 Kepala Daerah Jadi Tersangka Korupsi di 2018. Www.news.detik.com. Accessed on May 4, 2018.

[7] [7] Haryudi. Tawuran Pelajar di Bogor, Satu Tewas Disabet Celurit. Www.metro.sindonews.com. Accessed on May 4, 2018.

[8] [8] Arief Ikhsanuddin. Tawuran Pelajar di Cengkareng Rusak Motor Ojek Online. Www.news.detik.com. Accessed on May 4, 2018.

[9] [9] W.J.S Poerwadarminta, Kamus Umum Bahasa Indonesia (Jakarta: Balai Pustaka, 1991), XII edition, p. 250.

[10] [10] Doni Koesoema, Pendidikan Karakter (Jakarta: PT Grasindo, 2007), p. 53.

[11] [11] Ahmad D. Marimba, Pengantar Filsafat Pendidikan Islam (Bandung: Al-Ma'arif, 1962), p. 19.

[12] [12] Ahmad Tafsir, Ilmu Pendidikan Dalam Perspektif Islam (Bandung: PT Remaja Rosdakarya, 2004), p. 25.

[13] [13] Hamid Fahmi Zarkasyi, Filsafat dan Praktek Pendidikan Islam Syed M. Naquib Al-Attas (Bandung: Mizan, 2003), p. 174.

[14] [14] Darmaningtyas, Pendidikan yang Memiskinkan, p.

[15] [15] Adi Sasono, Solusi Islam Atas Problematika Umat (Jakarta: Gema Insani Press, 1998), p. 123.

[16] [16] BayraktarBayrakli,Prinsip \& Metode Pendidikan Islam (Depok: Inisiasi Press, 2004), p. 128.

[17] [17] Syaifulloh Yusuf, Kepemimpinan Prof. Zaini Dahlan, MA dan Kontribusinya terhadap Pendidikan Islam, Thesis (Yogyakarta: UIN Sunan Kalijaga Yogyakarta, 2015), p. 19.

[18] [18] Recorded on university meeting on Agustus 2, 2018, VIP meeting room, Rektorat UII 3rd floor.

[19] [19] Wahyu. 2011. Masalah dan Usaha Membangun Karakter Bangsa. Jurnal Komunitas Pendidikan Sosiologi FKIP Universitas Lambung Mangkurat. p, 140.

[20] [20] Hermawan. 2017. Implementasi Pendidikan Karakter Berbasis Masyarakat Pada Kegiatan Student Exchange SD Muhammadiyah Paesan Pekalongan. Jurnal Pendidikan Agama Islam - Ta'lim Vol 15 No.2, p. 115.

[21] [21] Bambang Harmanto. tt. Pembentukan Karakter Anak Melalui Softskill Training, p.4.

[22] [22] Marzuki. 2012. Implementasi Pendidikan Karakter Berbasis Nilai Agama. p. 4. Paper presented on Seminar dan Sarasehan Dosen dan Tutor Pendidikan Agama Islam Semester Gasal 2012/2013, Rabu, Oktober 3, 2012 in Ruang Sidang Utama LPPMP UNY.

[23] [23] Feri Jon Nasrullah. 2015. Pendidikan Karakter pada Anak dan Remaja. Program Studi Magister Psikologi, Universitas Muhammadiyah Malang. Paper presented on Seminar Psikologi dan Kemanusiaan. p. 483. 
[24] [24] Yulia Citra. 2012. Pelaksanaan Pendidikan Karakter dalam Pembelajaran. Jurnal Ilmiah Pendidikan Khusus, Jurusan PLB FIP UNP. Vol 1. No. 1. p. 248.

[25] [25] Rukiyati dan L Andriyani Purwastuti. 2016. Model Pendidikan Karakter Berbasis Kearifan Lokal Pada Sekolah Dasar di Bantul Yogyakarta. Jurnal Pendidikan Karakter, tahun VI, No. 1. p. 141.

[26] [26] Zubaidi. 2011. Desain Pendidikan Karakter Konsepsi dan Aplikasinya dalam Lembaga Pendidikan. (Jakarta: Prenada Media Group). p. 18.

[27] [27] Muhammad Arif Ihwanto, et all. 2017. Desain Pendidikan Karakter Berbasis Nilai-nilai Ihsan bagi Siswa MI NU Salafiyah Kudus. In Innovative Journal of Curriculum and Educational Technology. Unnes. p. 4.
[28] [28] Muhammad Arif Ihwanto, et all. 2017. Desain Pendidikan Karakter Berbasis Nilai-nilai Ihsan bagi Siswa MI NU Salafiyah Kudus. In Innovative Journal of Curriculum and Educational Technology. Unnes. p. 5.

[29] [29] Muhammad Arif Ihwanto, et all. 2017. Desain Pendidikan Karakter Berbasis Nilai-nilai Ihsan bagi Siswa MI NU Salafiyah Kudus. In Innovative Journal of Curriculum and Educational Technology. Unnes. p. 10.

[30] [30] Presented by Agung Nugroho Adi, ST., MT on Prajabatan Dosen UII, Agustus 6 2018, in Hotel Santika Yogyakarta.

[31] [31] Ibrahim Basyuni. 1969. Nash'ah Tasawwuf AlIslam, (Kaherah : Darul Fikri), p. 17. 